\title{
Contrarian Investment Philosophy in the American Stock Market On Investment Advice and the Crowd Conundrum
}

\author{
Bondo Hansen, Kristian
}

Document Version

Accepted author manuscript

Published in:

Economy and Society

DOI:

10.1080/03085147.2015.1109806

Publication date:

2015

License

Unspecified

Citation for published version (APA):

Bondo Hansen, K. (2015). Contrarian Investment Philosophy in the American Stock Market: On Investment Advice and the Crowd Conundrum. Economy and Society, 44(4), 616-638.

https://doi.org/10.1080/03085147.2015.1109806

Link to publication in CBS Research Portal

\section{General rights}

Copyright and moral rights for the publications made accessible in the public portal are retained by the authors and/or other copyright owners and it is a condition of accessing publications that users recognise and abide by the legal requirements associated with these rights.

Take down policy

If you believe that this document breaches copyright please contact us (research.lib@cbs.dk) providing details, and we will remove access to the work immediately and investigate your claim. 


\title{
Contrarian Investment Philosophy in the American Stock Market: On Investment Advice and the Crowd Conundrum Kristian Bondo Hansen
}

\author{
Journal article (Post print version)
}

Cite: Contrarian Investment Philosophy in the American Stock Market : On Investment Advice and the Crowd Conundrum. / Bondo Hansen, Kristian. In: Economy and Society, Vol. 44, No. 4, 2015, p. 6l6-638.

This is an Accepted Manuscript of an article published by Taylor \& Francis in

Economy and Society on 06 January २०16, available online:

http://www.tandfonline.com/10.1080/03085147.2015.1109806

Uploaded to Research@CBS: September २016

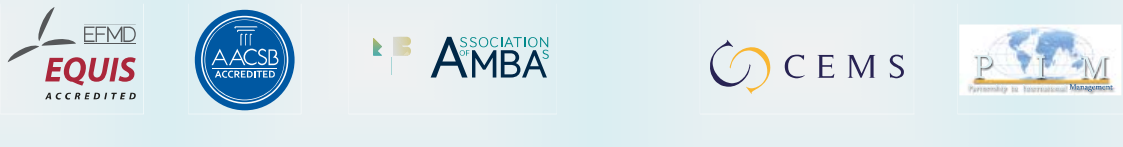




\title{
Contrarian Investment Philosophy in the American Stock Market: On investment advice and the crowd conundrum
}

\begin{abstract}
This paper contributes to the understanding of the role of crowds in the financial market by examining the historical origins and theoretical underpinnings of contrarian investment philosophy. Developed in non-scientific, practice-oriented 'how to' handbooks in 1920s and '30s America, contrarian investment advice was aimed at so-called small investors rather than well-established market practitioners. Emerging out of late-19th- and early-20th-century debates about public participation in the stock market, the contrarians expanded on a widely held (amongst financial writers) skepticism about the investment and speculation skills (or lack thereof) of the masses and adopted ideas from the theoretical discipline of crowd psychology, whereby they positioned the mass (i.e. the crowd) in opposition to the successful investor. I argue that despite its idiosyncrasies, the contrarians' conception of the market based on crowd psychology, points to a fundamental fragility of market participants, which still lingers on in recent debates about the wisdom of financial market crowds.
\end{abstract}

Keywords: financial markets; contrarian investment; crowd psychology; the public; 'how to' handbooks; wisdom of crowds.

\section{Introduction}

It is an axiom in Wall Street that "the public is always wrong," Patton Thomas (Thomas, 1900) 
The public may be unintelligent; but the stock exchange can boast but few who have been able to

oppose it with impunity.

Henry Crosby Emery (Emery, 2012 [1896])

The idea that the average of a group's judgments provides a more reliable and thus precise measure than that of an individual expert - an idea popularized by James Surowiecki in his popular-science bestseller The Wisdom of Crowds: Why the Many Are Smarter Than the Few (Surowiecki, 2005) - has been tested in and substantiated by several recent studies of the stock-price prediction capabilities of various online communities, i.e. crowds (Bollen, Mao, \& Zeng, 2011; Chen, De, Hu, \& Hwang, 2014; Gottschlich \& Hinz, 2014; Hill \& Ready-Campbell, 2011; Nofer \& Hinz, 2014; Zhang, Fuehres, \& Gloor, 2011). Throughout the popular history of financial investing and speculation, the ability to predict price fluctuations in the stock market has been a desired aim - and, in many ways, a fantasy. However, that the crowd should supposedly generate the most accurate forecasts is quite surprising considering the role of 'the masses' in early-20th-century popular discourse on stockmarket trading.

In 1934, psychologist and marketing researcher Daniel Starch wrote that the stock market was a 'giant psychometer' measuring 'America's psychological temperature' (Starch, 1934, p. 112). Rendering the psychological state of the nation in price quotations seemed fitting for an American society still dilapidated after the 1929 crash, which had brought to an abrupt halt the speculative craze of the 1920s (Malkiel, 2012, p. 48). Two years before Starch, the esteemed financier Bernard Baruch had written that '[a]ll economic movements, by their very nature, are motivated by crowd psychology', and further argued that, in order to understand how financial markets work, it is essential to first acknowledge that crowdpsychological traits are embedded in the nature of economic fluctuations (Baruch, 1932, p. xiii). The drawing of causal links between the public's collective psyche and stock-price fluctuations was not, however, a new phenomenon. Commentators, regulators, practitioners and academics had been doing so since the late 19th century, 
when the question of public participation in speculation was a relatively common discourse. A frequently voiced concern in this debate was that the susceptible minds of inexperienced public speculators, acting en masse, would lead to mob action, mass hysteria, and even panic in the market. According to many writers on the subject of financial markets and speculation, those wanting to do business in financial markets were increasingly interested in accounting for crowd-psychological influences:

One may remain aloof from such [mass psychological] influences, but one cannot engage in business apart from them. To that extent the individual must sink or swim with the mass.

(Winkelman, 1932, p. 336)

However, for the exponents of the contrarian investment approach, the choice was not merely one of either sinking or swimming with the masses. The rationale of the contrarian approach, as articulated in early-20th-century 'how to' handbooks, was basically that, since markets were made of people, and since people were gregarious by nature, i.e. susceptible to becoming blind followers of the crowd, upward or downward fluctuations were not to be taken at face value. Rather, such fluctuations were seen as expressions of collective emotion, opinion, or sentiment, but rarely reflections of real changes in the value of the stock. As such, the contrarians thought that the individual needed to fight the urge to follow the herd, and instead oppose it - in other words, be contrary (Kelly, 1930, p. 59). The epitome of the contrarian approach was Humphrey Bancroft Neill, who, according to the Oxford English Dictionary, coined the noun 'contrarian' in his 1954 book The Art of Contrary Thinking (Neill, 1963a [1954]).

Although the term 'contrarian' originated in the mid-20th century, and Neill first began writing about contrary thinking in the early 1920s, the systematic counteracting of the major tendencies in the market, which was associated with beartrading (short-selling), can be traced back to Joseph de la Vega's Confusion de Confusiones from 1688 (Vega, 1996). ${ }^{1}$ The historical trajectory of this paper does not 
extend as far back as de la Vega, but starts with the aforementioned debate about public participation in the stock market. It follows how crowd psychology gained prominence in popular discourse on financial markets, and argues that the debate about public participation in, and the popularization or democratization of financial speculation (depending on the perspective) created a stigmatizing stereotype of the public and of the individuals that constitute it - something that came to shape the contrarians' view of the market. The axiom that the public, the mass, the crowd were not qualified to speculate was used to underpin the strategic advantage of the contrarian approach.

However, the idea that crowds are almost by definition ignorant has recently been challenged and refuted in several online studies of crowds' ability to predict the price of stocks more accurately than experts. Generally speaking, these studies support the wisdom-of-crowds hypothesis, and thus seem to dispel the notion of the intellectual inferiority of crowds (compared to the isolated individual) expressed in crowd psychology. Conversely, as I will show in the last part of the paper, some of the conditions required for a crowd to be 'wise' are actually in consonance with the preventive measures advocated by the 'how to' handbooks on contrarian investment. In the case of both the wise and the ignorant crowd, what appears to be most important is understanding the susceptibility of the individual in the social, in order to prevent this susceptibility from coloring the individual's judgment. From diametrically opposite starting points, the crowd-psychology-informed pessimism of the contrarian and today's newfound praise of crowd wisdom seem to intersect in an emphasis on the fragility introduced into the financial market by human suggestibility. Based on a historical outline of the origins and crowd-psychological underpinnings of an (in an academic context) sparsely discussed, but (as I attempt to illustrate) significant investment philosophy, the paper contributes to the unfolding of one of the major conundrums of financial market literature - namely, the role of the social, and thus the collective, in markets.

The paper is divided into four parts. The first part outlines and examines the characteristics of and the knowledge produced in the 'how to' handbooks. It also 
contains a brief introduction to crowd psychology. The second part demonstrates how financial writers dealt with the popularization of financial speculation, and how, in the process, they produced and reproduced a stigmatizing characterization of the public as inexperienced, incompetent, and lacking the mental poise needed to succeed in speculative endeavors or even contribute to the common good. The third part of the paper follows the emergence of contrarian speculation in the 1920s and '30s, and examines how proponents of the contrarian approach employed crowd psychology in their work, and the consequences of this for their perception of the market. In the fourth and final part, I discuss the recent turn away from the intellectually inferior crowd and toward crowd wisdom. The wisdom of crowds appears to render antiquated the contrarians' crowd-psychology-based conception of the market, but, on the contrary, it reaffirms some of the contrarian skepticism regarding social dynamics in markets.

\section{Crowds, popular knowledge, and investment advice}

Financial literature advising people how to invest, and more generally how to administer their fiscal responsibilities, may predate the beginnings of the contrarian approach in the early 20th century, but its characteristics changed significantly during this period. Earlier financial advice literature had served as a guide to good citizenship, defined to some extent by the responsible management of personal and family finances. However, the 'how to' literature produced by the likes of Humphrey Neill was somewhat different. These books, pamphlets, and newsletters did not seek to turn people into better citizens, but to provide investment advice to a specific segment of society - namely, aspiring speculators. The idea was not to make amateurs into professionals, or outsiders into insiders. Instead, the authors of these writings claimed, generally speaking, that successful financial speculation did not necessitate being either a professional trader or a market insider. Market psychology, a central topic in most of these writings, somewhat leveled the playing field, because it made everyone a potential victim of bad judgment caused by some kind of 
emotional contagion. As long as they were given good advice, anyone could potentially become a successful trader. For that reason, most of these books include passages, mostly toward the end, on how to tame emotions and control the mind in order to make rational, emotionally unbiased choices and therefore avoid being led astray by the opinionated market public. One of several examples is Frank J. Williams' If You Must Speculate, Learn the Rules (Williams, 1930), which concludes with an exhaustive list of so-called 'golden rules' of financial speculation. These rules are very basic and appear realistically achievable, e.g. '[t]he market is most dangerous when it looks best', '[d]on't speculate unless you have plenty of time to think about it', and '[d]on't let emotion and prejudice warp your judgment' (Williams, 1930, pp. $91-4)$.

In order to be a successful investor, the aspiring reader was tasked with putting into practice the rules and advice given in the 'how to' books. It is precisely in this dynamic - between the person in need of advice on how to invest and speculate properly (the reader) and the actual 'how to' or self-help book - that the paradoxical nature of this type of literature lies (Cherry, 2008). Reading does not in itself fulfill the needs of the person who wishes to become a successful investor; rather, it suspends and denies the reader the opportunity to practically actualize the self-help tools and techniques made available in the books. Ironically, the 'how to' book cannot supply that which the reader demands - namely, the actualization, not the receiving of self-help (Cherry, 2008, p. 346). Also somewhat paradoxical is that many of the 'how to' handbooks actually detest the idea of investment advice, claiming that, although easily comprehensible, such advice seldom leads to success when applied in practice, and that the advice was necessarily of questionable quality since the advisors were authors of 'how to' books rather than successful investors (see, e.g. Harper, 1926, pp. 8-10). Apart from their idiosyncrasies and paradoxical nature, the 'how to' books produced an accessible and practical form of knowledge that appealed to a wide audience. Whether described as 'grassroots' (Knight, 2012, p. 1059) or 'vernacular' (Poitras, 2011; Preda, 2004), the significance of the knowledge produced in these books was its reliance on the reader to actualize the knowledge in 
practice. According to Alex Preda, sources of vernacular knowledge such as the "how to' book provided the reader with 'know-how, techniques and rationalization procedures that help social actors make sense of their economic environment and the economic consequences of their actions', which distinguished them profoundly from the 'abstract, and formalized explanations' found in academic literature (Preda, 2004, p. 354).

Due to their lack of stringency, these books are often unclear as to whether the public and the crowd are considered two sides of the same coin, e.g. 'the so-called crowd - i.e. the public (Moore, 2005 [1921], p. 112, italics in the original). Elsewhere, the public is referred to as 'the multitude of small traders', which designates the many in the market without the unifying connotations of 'the crowd' (Selden, 1912, p. 21). Additionally, there are at least three usages of the term 'crowd' in popularized financial writings. The first refers to the physical mass of traders going about their business on the virulent open-outcry trading floor of the exchange. In this understanding, the crowd occupies a physical space that can be entered (Wyckoff, 1910, pp. 28-9). The second is as a designation for groups on the trading floor associated with a particular stock, and thus a particular company, e.g. the 'Standard Oil crowd' (Selden, 1912, p. 37). Thirdly, any major tendency in the market is described in terms of there being a crowd in the market, which investors are subconsciously inclined to follow (Wyckoff, 1910, p. 18). When the contrarians used the term, they were not only referring to the lay understanding of the collective psyche of the body of investors and speculators. Some were also referring to crowd psychology as described in academic theory. Urs Stäheli has carefully examined the contrarians' use of crowd-psychology theory (Stäheli, 2006, 2013). In his analyses, he focuses primarily on the self-disciplinary techniques employed by the ideal contrarian, but for the most part he does not address the historical traces and connections to the wider debate on the masses' participation in financial markets. In other studies, concepts from crowd psychology have been revisited in order to revitalize this allegedly neglected tradition, and to engage with economic life from an alternative theoretical position (Arnoldi \& Borch, 2007; Borch, 2007). Yet another 
notable study is Charles W. Smith's sociological inquiry of the 'crowd syndrome' in financial markets, in which he delivers a critique of contrarian investment strategies (Smith, 1999).

Crowd psychology itself emerged during the 1890s as a theoretical sub-discipline under social psychology and sociology, via central exponents such as Gabriel Tarde and Gustave Le Bon (Borch, 2012). To give a crude, general idea of how its exponents conceptualized the crowd, I turn to Le Bon's definition of the 'psychological crowd' from The Crowd, which was adopted by the contrarian Thomas Temple Hoyne. Le Bon defined the psychological crowd as:

[A] provisional being formed of heterogeneous elements, which for a moment are combined, exactly as the cells which constitute a living body form by their reunion a new body which displays characteristics very different from those possessed by each of the cells singly.

(Le Bon, 2001 [1895], p. 4)

Ideas from crowd psychology were, albeit exceptionally, mobilized to account for the social and psychological characteristics of financial market participants as early as 1900. In his book Economic Crises, Edward David Jones, assistant professor in economics at the University of Wisconsin, was influenced by Tarde's idea that social life fundamentally consisted of imitative processes, and that city life was a 'concentrated and exaggerated type of social life' (Tarde, 1903, p. 84, p. 87). For Jones, markets were further exaggerations of an (in terms of sociality) already exaggerated and concentrated urban environment, which increased the risk of contagious, unsubstantiated views and opinions being imitated and spreading like epidemics in dense metropolises. This concentration and proximity of people could explain 'the unthinking ferocity of mob action' in markets. Mob action was a term Jones discussed with reference to another exponent of crowd psychology, the Russian-born psychologist, physician, psychiatrist, philosopher, and student of William James at Harvard, Boris Sidis (Jones, 1900, pp. 204-5). Like Le Bon, Sidis 
focused primarily on the violent sides of crowd behavior, and furthermore argued that modern democratic society (which, in its American form, he had come to know quite well) was a cradle of mob behavior (Leach, 1986, p. 102; Sidis, 1919 [1898]). The skepticism toward and fear of 'mobocracy' was shared by many within the financial market, which colored perceptions regarding the masses' participation in the stock market (Fraser, 2008, p. 20).

In the following section, I suggest that the debate about the role of the masses (i.e. public participation) in the stock market produced and reproduced a stereotyped understanding of the speculating public and the individuals that constitute it. By rendering members of the market public intellectually inferior and psychologically unfit for speculation, financial writers cast doubt about whether market movements were due to changes in the fundamental factors underlying the price of assets or to crowd psychology - a problematic situation that the contrarian approach would answer in a very particular way.

\section{Public $^{2}$ participation: the emergence of the market crowd}

To the inexperienced Wall Street is ever an alluring light, toward which men seem drawn by some peculiar power. Continually the moths keep flying into the flame, until their wings are scorched off and their charred carcasses fall at the foot of the candle with swarms of the other dead.

(Keyes, 1904, p. 45)

During the Gilded Age, financial markets and speculation became very popular among the American public. At the time, a fairly small aristocracy of businessmen and financiers, sometimes referred to as the plutocracy or gentlemen's rule of Wall Street, dominated and, to a large extent, ruled the financial markets (Fraser, 2008, pp. 29-30; Pak, 2013). Even though it conflicted with the interests of the Wall Street plutocracy, financial speculation, which was still often bracketed with horse-racing and other forms of gambling, seemed to have a mysterious appeal for the masses 
(Cowing, 1958, p. 405). This increased engagement with financial market activities was at least partially due to a proliferation of popularized speculation- and stock market-related stories in magazines, newspapers, and books, both fiction and nonfiction (Knight, 2012; Zimmerman, 2006). In addition, the public got a taste of and feel for speculation in the so-called bucketshops - small betting shops where ordinary people, unaffiliated with the exchanges, could bet on an increase or decrease in the price of certain stocks. The bucketshop owners took on all of the risk themselves, trusting in the truth of the axiom 'the public is always wrong' (Hochfelder, 2006, pp. 335-6; Kindleberger \& Aliber, 2011, pp. 46-7; Thomas, 1900, p. 68). Considered nothing more than basic betting, bucketshop speculation was loathed by advocates of the organized exchanges, such as financial journalist Charles A. Conant. He claimed that bucketshop gambling was 'destructive to the morals and pockets of young men' and reminded his readers that, despite the superficial similarities, bucketshops were by no means 'miniature exchanges' (Conant, 1901, pp. 709-10, 1904, p. 85). ${ }^{3}$ One consequence of this increased public interest was that many accounts of the stock market, both popular and academic, sought to understand or prophetically anticipate the implications of public participation in financial speculation. Several of these accounts contributed to a production and reproduction of a simplistic yet forceful conceptualization of the public in the financial markets. One such account is found in Max Weber's 'Die Börse' (1894), a largely descriptive, yet at times polemic comparative account of the organization of North American, German, French, and British stock and commodity exchanges. Weber argued that the public should not be allowed to speculate in the restricted space of the exchange:

The exchange is the monopoly of the rich, and nothing is more foolish than to disguise this fact by admitting propertyless, and therefore powerless, speculators and in that way to allow large capital holders to shift responsibility away from themselves and onto those others.

(Weber, 2000 [1894], p. 334, italics in the original) 
Unequivocally opposed to small speculators being granted access to the stock exchange, Weber instead suggested that these 'superfluous parasites' on the national economy directed their work towards 'virtually any other useful activity' (Weber, 2000 [1894], p. 333). Dismayed and vexed by the negative impact of the participation of incapable persons in the exchanges, he wrote that 'the mishmash that now constitutes our "public" on the exchanges will never have its pronouncements respected; the precondition for that, a unified "concept of honor", is lacking' (Weber, 2000 [1894], p. 334). The proposed solution to the problem of the invasive horde of small speculators was twofold. First, traders had to be properly educated by seasoned traders; second, the exchanges had to 'make entrance into the exchanges more difficult by requiring stronger monetary guarantees', which Weber believed would reinstall the exchange's honor and honesty (Weber, 2000 [1894], p. 334, italics in the original). Although supposedly viable in a Continental European context, discriminating against people from a lower economic class was incompatible with the principles of equality that were firmly embedded in the constitutional foundation of American society (Cowing, 1958, p. 18). Henry Crosby Emery, an American economist and expert in the organization of European and North American exchanges, stressed that the German attempt to 'restrict the participation of the public in reckless speculative trading' was 'utterly foreign to American conceptions' (Emery, 2012 [1896], p. 71). However, Emery was torn over the question of public participation - on the one hand, he believed that more traders in the market would provide liquidity, and yet, on the other, he shared the doubts regarding the inexperienced commoners' ability to trade (Emery, 2012 [1896], p. 59).

Many American financial writers were convinced that restricting the public from participating in financial speculation, as Weber suggested, would be neither possible nor reasonable. However, free-market apologists such as Emery and Conant agreed with Weber that traders needed to be properly educated if the stock market was to keep on serving the common good of society, as they genuinely believed it should. If the public was to engage in financial speculation, it had to be lifted out of financial 
illiteracy by those familiar with the stock-market 'game'. Brokers and traders should recognize their fiduciary relationship to the public and take an active part in enlightening it (Cowing, 1958, p. 19). Essentially, a principal duty of the stock exchanges was to 'protect the public against dishonesty and fraud', which entailed not allowing manipulators to pervert the exchange's 'essential functions' (Conant, 1903, p. 434; Emery, 2012 [1896], p. 56).

Not all writers had the same faith in financial market activities' causal relation to general societal prosperity. One harsh critic of financial speculation, William E. Forrest Hoyle, claimed that ' $[\mathrm{t}]$ here is no business in the world that, win or lose, is so sure to wreck soul, mind, and body, as is Wall Street speculation' (Hoyle, 1898, p. 15). To Hoyle, financial speculation was just as much of a game as Whist, and speculators were essentially gambling 'parasites', piggybacking on the value-creation of others (Hoyle, 1898, p. 13). Unsurprisingly, stock-market advocates strongly contested opinions such as Hoyle's. One such advocate was Samuel Untermyer, lead interrogator in the Pujo Committee's investigation of the so-called money trust on Wall Street, who had 'no patience with the legislators, agitators, demagogues, and ignoramuses throughout the country who regard the Exchange as a sort of gambling den or its membership as a coterie of gamblers whose activities should be suppressed' (Pak, 2013; Untermyer, 1915, p. 25). Somewhat ironically, Hoyle's criticism of stock-market speculation appeared in his 1898 'how to' handbook The Game in Wall Street: And how to play it successfully, in which he offered advice to amateurs. He argued that because the public had little chance of success in the stock market, amateur speculators had to outsmart other members of the market public by getting in 'when the majority think prices are going down' and 'out when they think the market is going higher' (Hoyle, 1898, p. 36). With a market public articulated as inexperienced, incapable, and easily manipulated, opposing the majority became less counter-intuitive and even, to a certain degree, a matter of common sense. It was also argued that psychological factors in the market, i.e. the whims and fancies of a volatile and easily excitable speculating public, could lead to violent fluctuations and, in the worst cases, panic (Conant, 1905, p. 354; Withers, 1910, pp. 308-9). The 
speculative temper of the general public made its constituents particularly susceptible to being swept away by the crowd or, in other words, having their mental machinery 'thrown out of gear' (Wyckoff, 1910, p. 17). The ascribing of psychological traits to a speculating public already stigmatized as incompetent and inexperienced made it increasingly important to distance oneself from the crowd.

Public participation increased significantly during and after World War I, propelled by, among other things, the Liberty Bond drives. Also known as war bonds, these were government bonds issued four times in the aftermath of the war, targeted at the American public as a whole (Cowing, 1965, p. 95). The war-bond schemes clearly signaled that a citizen's obligations not only entailed voting, but also participation in the financial system for the betterment of the economy and, consequently, society (Perkins, 2012). Although financial writers had noted the potential proliferation of investing and speculation among the masses, less than $1 \%$ of the American population owned stocks or bonds at the turn of the century. This changed with the WWI bond drives, during which approximately one-third of the population purchased bonds. In 1929, before the crash, around a quarter of American households owned shares in a publicly traded company (Ott, 2011, pp. 12). ${ }^{4}$ Other factors that contributed to the increase among the investing or speculating public were employee stock-ownership plans and the banning of bucketshops, the former customers of which rushed to the legitimate exchanges. The successful eradication of bucketshops in 1915, following many years of legal dispute and a smear campaign by the established exchanges, altered the exchange officials' view on small speculators - instead of being kept at arm's length, they were encouraged to partake in market activities (Hochfelder, 2006, pp. 337-8, pp. 355-7). According to Don Guyon (pseudonym), author of One-Way Pockets: The Book of Books on W all Street Speculation, the increased popularity of speculation during the war years led to calls for investment strategies that opposed the decisions of the 'consistent losers in Wall Street', i.e. the public (Guyon, 1917, p. 63). Based on the maxim 'the public's speculative play is wrong', the strategic proposition was that there seemed to be a reasonable chance of winning the Wall Street game 'i]f the opposite plan of 
operations can be adhered to' (Guyon, 1917, p. 31). Carrying out such a contrary plan required a 'detached, unprejudiced frame of mind, and to study the psychology of the crowd, especially as it manifests itself in the movement of prices' (Selden, 1912, p. 67).

Psychology was indiscriminately used to explain alleged economic irrationality, often without substantive evidence or reference to academic tradition (see, e.g. Hamilton, 1922, p. 246). However, this engagement with the human element or the

psychological factor only increased with the proliferation of 'how to' handbooks in the early 20th century. This undercurrent of popularized market psychology was partly enmeshed in academic theory, in the sense that several of these writings were influenced by the budding sub-discipline of crowd psychology. The following section examines how exponents of the contrarian approach to speculation used crowd psychology to substantiate their idea of the market as ultimately influenced by the collective psyche of its participants. By relying on the ignorance of the public or the masses, the contrarian approach grew out of an overriding mistrust in the public's ability, or lack thereof, to trade in financial markets. Ironically, it was precisely the amateurish public speculator whom the contrarians wanted to reach with their investment advice.

\section{Contrarian market philosophy}

$[\mathrm{H}]$ uman nature in the stock market is going to be the most profitable study in the next bull market. The greater the number of traders, the more necessary will it be to study and to know market psychology and have a market philosophy.

(Neill, 2007 [1931], p. 131)

A 1923 advertisement brochure for the New York-based investment consultancy Neill-Tyson Inc. suggested that 'being intelligently contrary is the safest market rule to follow' (Neill, 1923, p. 4). ${ }^{5}$ Because average persons were easily encouraged to buy when prices were advancing, but often paralyzed and unable to sell during 
downturns, the safest way to operate in the market was to deprive oneself of one's averageness, i.e. not to align one's thinking with public opinion (Neill, 1923, p. 4). Humphrey B. Neill of Neill-Tyson Inc. further developed and refined this investment advice, eventually formalizing what he termed the theory of contrary opinion. His thoughts on investing later formed the theoretical basis for Fidelity Investments' Fidelity Contrafund (founded in 1967), which is today one of the world's largest mutual funds. ${ }^{6}$ During the 1920s heyday, Neill was active in Wall Street, but after Black Tuesday left him near-bankrupt, he turned his attention to writing about the stock market rather than conducting business in it. Considering himself a 'socio-economic journalist', Neill disseminated his thoughts via newsletters, newspaper columns, small commercial brochures, and books (Schultz \& Coslow, 1966, p. 325). One such medium was the monthly commercial brochure If, As \& When: Passing Thoughts and Reflections on Human Nature in Finance, ${ }^{7}$ published during the first few years of the Great Depression. If, As \& When focused on analyzing the 'human element' influencing stock-market action, and the difficulty of suppressing or taming the allegedly inborn urge to run with the crowd.

The 1929 crash taught Neill that the public was naturally susceptible to throwing reason to the wind and blindly following the crowd. He argued that the circumstances behind the crash were principally psychological (Neill, March 1930, pp. 10-1; April 1930, p. 12). In Tape Reading and Market Tactics, he suggested that the market's collapse made it clear that the susceptible market psyche necessitated ways of trading that opposed the 'uninformed, unintelligent public' (Neill, 2007 [1931], p. 13). These initial thoughts on trading against the market were influenced by the contrarian Fred C. Kelly's 'how to' book Why You Win and Lose, which Neill praised in $A s$, If \& When (Neill, September 1930, p. 16). Kelly argued that, in order to understand the market, one had to account for 'the great mass of unthinking speculators and investors who are going to be wrong'. In order to outperform the market, one had to 'be contrary' to it, even if this seemed illogical (Kelly, 1930, pp. 58-9, p. 17). What John Maynard Keynes later called improper stock valuation, 'established as the outcome of mass psychology of a large number of ignorant 
individuals' (Keynes, 1936, p. 154), Kelly and Neill perceived as a pre-given condition in the market, hence something of which to take advantage in a strategic manner.

The actual contrary market philosophy, or 'theory of contrary opinion', was first formalized in the 1951 pamphlet It Pays to be Contrary, which later became a part of Neill's book The Art of Contrary Thinking. In this book and in his bi-weekly newsletter, Neill Letters of Contrary Opinion, published between 1939 and 1974, Neill draws explicitly on Le Bon's notion of the crowd and Tarde's notion of imitation (Neill, 1963a [1954]). In order to take advantage of the crowd's deficiencies, the contrarian should first and foremost make sure not to become part of it. This required adopting certain techniques to protect oneself from the contagiousness of the market crowd. Neill suggested that speculators used a pad and pencil to occupy the mind and increase their focus, as they strived to become 'a clam, an unpleasant cynic', refraining from uttering any opinions (Neill, 2007 [1931], pp. 85-6). In the December 1930 issue of If, As \& When, Neill, writing under the pseudonym 'The Market Cynic', listed ten ways to lose money on Wall Street:

1. Put your trust in the board-room gossip.

2. Believe everything you hear, especially tips.

3. If you don't know, guess.

4. Follow the public.

5. Be impatient.

6. Greedily hang on for the top eight.

7. Trade on thin margins.

8. Hold to your opinion, right or wrong.

9. Never stay out of the market.

10. Accept small profits and large losses.

(Neill, December 1930, p. 2) 
The one piece of advice that summarized the contrarian approach was to 'sell before the public on the signal of the increased volume and price activity which mark turning points' (Neill, 2007 [1931], p. 89, italics in the original). However, how such turning points could be detected in the market was not crystal clear. In his bi-weekly newsletter, Neill Letters of Contrary Opinion, published between 1939 and 1974, Neill was more direct with regard to how one could determine that the time was right to counteract the market. These short newsletters usually started out with an overview of the market, as forecasted in the financial news. This was then followed by a forecast in which Neill contradicted the mainstream media's predictions (see e.g. Neill, Jan. 9, 1963). ${ }^{8}$ One supporter of this approach to investing was Robert L. Smitley - another former Wall Street professional, whose early work reminded Neill of the importance of crowd psychology (Neill, July 11 1951, May 15). In the book Popular Financial Delusions (inspired by Charles MacKay's famous history of popular folly Extraordinary Popular Delusions and the Madness of Crowds (Mackay, 2001 [1841])), Smitley argued that trading in accordance with the dictates of psychology sometimes necessitated disobedience to economic imperatives - something that required great poise and conviction. Polemically, he stated that because crowd psychology played such a significant role in the market, speculators must be 'capable disciples of the great Frenchman, Gustav Le Bon’ (Smitley, 1933, pp. 114-6, p. 277).

Another contrarian who mobilized ideas from crowd psychology was Thomas Temple Hoyne. In Speculation: Its Sound Principles and Rules for its Practice, Hoyne argued that since all price fluctuations in the market were caused by 'speculative force', it was of utmost importance for the speculator to fully understand how this force grows stronger or weaker, why it changes its direction and the manner in which it is transformed into active power in the market' (Hoyne, 2012 [1922], p. 34). In order to initiate the average speculator in the psychology of the market, Hoyne introduced Le Bon's notion of the psychological crowd as emblematic of social organization in stock markets (Hoyne, 2012 [1922], p. 34, p. 58). Thought of as the 'most important incident to speculative markets' and as a means of illuminating the suggestion and contagion underlining market action, crowd psychology was duly placed at the center 
of Hoyne's market analysis. He argued that the ideal speculator was a 'paragon', 'impervious to crowd contagion', and although average speculators would never be able to compete with Hoyne's ideal, they nevertheless had to strive to attain a fraction of his or her intellectual mastery. As well as sticking to four rules of thumb, ${ }^{9}$ speculators should 'never buy or sell on impulse', never become 'poisoned emotionally', and never allow themselves to be 'swept into unconscious unity of crowd action' (Hoyne, 2012 [1922], p. 56). Strong-willed speculators needed to observe 'impulsive trading in others, such purely animal responses to greed, fear and crowd influence', in order to become aware of when to follow the crowd and when 'acting contrary to a great speculative group' would be more profitable (Hoyne, 2012 [1922], pp. 55-6, 58). Although he largely adhered to the position of those financial writers who believed that the market crowd was wrong more often than not, Hoyne did not rule out the possibility of the opposite scenario occurring. Neither did Neill, who stated that the crowd was 'right during the trends but wrong in both ends' (Neill, 1963, p. 42).

Unlike Hoyne, and to some extent Neill, R. W. McNeel had little to no faith in the abilities of the market crowd. As financial editor of the Boston Herald, author of the popular 'how to' handbook Beating the Stock Market (McNeel, 1921), and investment counselor at McNeel's Financial Services, McNeel had several points of contact with the financial market (Galbraith, 1975, pp. 67-8). Like Le Bon, McNeel perceived the crowd as intellectually inferior to the individual. In support of this argument, he referred to the intelligence tests performed in the army, which showed that in an average company of men, 20 per cent possess a certain amount of initiative, 60 per cent will follow the crowd, and 20 per cent are cowards by heart' (McNeel, 1921, p. 25). Because the stock market was a (zero-sum) game 'to be beaten', someone had to lose - and that someone had to be the public (McNeel, 1921, pp. 14-5). Fifteen years later, such cynicism made a dismayed and distraught Keynes assert that "the most skilled investment to-day is "to beat the gun" [...] to outwit the crowd, and to pass the bad, or depreciating, half-crown to the other fellow' (Keynes, 1936, p. 155). Yet for McNeel - and, for that matter, the other 
contrarians - there seemed to be no alternative to outwitting the crowd if profits were to be made in speculative markets. The simple reason for this was that the stock market was indisputably under the influence of 'the contagious enthusiasm of the crowd', which played out in the form of intersubjective processes of unconscious imitation (McNeel, 1921, p. 153):

By unconscious imitation or sympathy, men catch the feeling of others and act in accordance with it. People become excited when others are excited, they are angry when others are angry, they mourn when others mourn, without any conscious exercise of intelligence.

(McNeel, 1921, p. 150)

Rendering market participants as spellbound by unconscious imitation, or as bewildered and 'not yet fully awake' (Bond, 1930, pp. 176-7), brings to mind Tarde's idea that social actors share traits with somnambulists (Tarde, 1903, p. 87). Like somnambulists, mentally intoxicated speculators were not to be relied upon. Although all traders were at risk of mental contagion, amateur speculators, due to their heightened tendency to lose their mental poise, were indisputably more susceptible (Harper, 1926, pp. 11-3). Neill also elaborated on the semi- and subconsciousness of people in a crowd. Although he did not go as far as saying that they were under complete unconscious hypnosis, Neill thought that there were many similarities between the actions of a crowd and hypnotic mesmerism (Neill, 1963a, p. 142). Tarde, whom Neill directly referenced when he claimed that the theory of contrary opinion hinged on 'the laws of imitation and contagion', provided an apt pair of counter-concepts to this position (Neill, 1963a, p. 104). The distinction between imitation and counter-imitation enabled Neill, albeit based on a reductive and selective reading of Tarde, to infer agency in Tarde's idea of the social as imitation. To Neill, both imitation and counter-imitation were choices, and therefore it was obvious that contrarian speculation was a conscious counter-imitative act, rather than a sub- or semi-conscious social process, as in Tarde (Neill, 1963a, p. 105; 
Tarde, 1903, p. 87). In that sense, in order to place orders in the market, the contrarian had to second-guess major tendencies in the market - in other words, critically assess whether a certain profound increase or decrease in a stock's price truly reflected a stock's value or was merely a fluctuation instigated by crowd behavior.

What the contrarians did was extrapolate a conception of the market as hinging on a basic understanding of crowd psychology - a conception that they repeatedly and continuously substantiated by emphasizing the market crowd's wrongdoings. Against this backdrop, it became almost counterintuitive, irrational even, to follow the decisions of the crowd. In a more contemporary context, however, the sociologist Charles W. Smith has criticized the contrarian approach precisely for its lack of trust in the crowd's ability to occasionally be right. Smith argues that contrarians are too preoccupied with the actions of the crowd - so much so that their own actions eventually become controlled by the crowd, 'almost as if they were part of it' (Smith, 1999, p. 164). By solely focusing their attention upon the actions of the crowd rather than its constituents, the contrarians reject the possibility of there being any qualitative differences between particular crowds at particular moments in the market.

During the last decade or so, there has been a significant shift in scholarly and popular scientific discourse on crowd and collective intelligence (or lack thereof). Le Bon's old proclamation that crowds accumulate stupidity, not 'mother wit' (Le Bon, 2001 [1895], p. 6), has been turned on its head by proponents of the wisdom of crowds, who claim that the crowd is intellectually superior (not inferior, as Le Bon claimed) to the isolated individual (Surowiecki, 2005, p. xvii). The following section discusses the ideas behind and prerequisites for the wise crowd, in the light of recent attempts to prove that crowd wisdom also applies to financial markets. If the market crowd is wise, rather than ignorant, contrarian strategies should be rendered redundant and crowd psychology obsolete in the financial market context. However, taking a closer look at the collective intelligence of the market crowd, it reveals itself as a fragile and susceptible construct that has more in common with the contrarians' 
crowd psychology-informed conception of the financial market than its proponents would perhaps admit.

\section{The market crowd: a stupidity-accumulator or a source of wisdom?}

When the British polymath Francis Galton analyzed the results of an ox-weighing competition at the annual West of England Fat Stock and Poultry Exhibition in Plymouth in 1906, he sought to conduct an 'investigation into the trustworthiness and peculiarities of popular judgments'. What he discovered was that the vox populi (measured as the mean of all the 787 guesses of the ox's weight) was much closer to the actual weight of the ox than the individual estimates. Much to Galton's surprise, democratic judgment had proved to be trustworthy - and indeed, very precise (Galton, 1907). According to Surowiecki, the study is a proven case of crowd wisdom. Instead of relying on the opinions and statements of experts, Surowiecki suggests that people simply ask the crowd, as Galton did in 1906, because '[c]hances are, it knows' (Surowiecki, 2005, p. xv). Basically, the wisdom of crowds is based on the idea that 'averaging all judgments will lead to a more accurate judgment than that of the average judge' (Gottschlich \& Hinz, 2014, p. 52), a hypothesis that has been tested in the financial market context by comparing experts' stock-price predictions to those of a range of virtual, internet-based communities and collectives. Recent studies of online crowds on social media platforms for investors (Chen et al., 2014; Gottschlich \& Hinz, 2014; Hill \& Ready-Campbell, 2011; Nofer \& Hinz, 2014) and on Twitter (Bollen et al., 2011; Zhang et al., 2011) have supported the claim that crowds can generate strong predictions of stock prices. Furthermore, a recent Journal of Finance paper shows that self-directed retail investors (today's equivalent of what were earlier referred to as 'small' or 'amateur' investors) are perhaps not 'unsophisticated, behaviorally biased, and otherwise uninformed' noise traders, but actually knowledgeable and able to predict stock returns (Kelley \& Tetlock, 2013, p. 1232 , 1263). These studies are not significant solely because they support the wisdom-of-crowds hypothesis, but because, in the process, they cast doubt on the 
reliability of expert verdicts - which are, under the right circumstances, trumped by the crowd. Non-professionals cannot be reduced to mere erratic noise traders who provide liquidity simply by virtue of being wrong (Black, 1986; Hoyle, 1898) - they have to be seen as part of a potentially rich reservoir of aggregated market knowledge.

In the paper 'Are Crowds on the Internet Wiser than Experts? The case of a stock prediction community', authors Michael Nofer and Oliver Hinz (2014) compared the predictions of professional analysts with those made by an online community devoted to stock-price forecasting. The study analyzes the precision of the crowd's predictions with regard to varying degrees of diversity and independence. Their analysis confirms the hypothesis that ' $[\mathrm{m}]$ embers of a stock prediction community on the internet $(=$ crowd $)$ are able to achieve a higher daily return than professional analysts (=experts)' and, furthermore, that '[a] higher degree of independence among the members of the crowd will increase the daily return of recommended stocks' (Nofer \& Hinz, 2014, p. 307, 310). As the study demonstrates, the precision of the crowds' predictions thus relies on the individual members' ability to make independent judgments. Motivation and group heterogeneity are also conditions that underpin the wisdom of crowds (Galton, 1907; Nofer \& Hinz, 2014, p. 307; Ray, 2006, p. 4). Although the different studies clearly indicate that under the right conditions the crowd can be proven intelligent, it is questionable whether the wisdom of crowds can be systematically and strategically employed in investing and forecasting, because a context such as the financial market seldom allows for the right conditions. For instance, it is exceptionally difficult to know whether traders act on the basis of their own private information or follow other traders. If the crowd is to be considered wise, 'crowd members should primarily rely on private information and follow their own beliefs instead of trusting other market participants' (Nofer \& Hinz, 2014, p. 325), but since stock prices are not static and traders are able to observe the actions of others (contrary to Galton's study, in which there was a right answer and where the participants were not able to copy each other), there is an imminent risk of imitation. Whereas the wisdom of a crowd is dependent on its 
members' independence, the contrarians advised investors to avoid the crowd, precisely in order to gain or sustain independence in their judgments. Becoming selfreliant and preventing social suggestibility were the main objectives behind Neill's controversial advice: 'trade alone' (Neill, 2007 [1931], p. 85). The ability to make independent judgments could therefore not be maintained within a crowd, but relied on isolation.

An important problem regarding the wisdom of crowds is the imminent risk of social influence, which has the negative consequence of diminishing the accuracy of the crowd's judgments. Lorenz et al. have shown (in an experiment in which the estimates of others were disclosed within the crowd, free from 'group leader effects, persuasion, or any other kind of social psychological influence') that a little social influence is enough to cause herding behavior and negative side effects for the mechanism underlying the wisdom of crowds' (Lorenz, Rauhut, Schweitzer, \& Helbing, 2011, p. 9024). The authors conclude that it is difficult, in a democratic society and an ideally transparent financial market, to generate a collection of independent estimates, since it is possible to observe what others are doing and because the media coverage has become extensive and almost omnipresent (Lorenz et al., 2011, p. 9024). The convergence of opinions often happens qua mimicry, which is the main driver in an informational cascade. Informational cascades occur 'when it is optimal for an individual, having observed the actions of those ahead of him, to follow the behavior of the preceding individual without regard to his own information' (Bikhchandani, Hirshleifer, \& Welch, 1992, p. 992). Thus, 'once a cascade starts, the private information of subsequent investors is never included in the public pool of knowledge' (Bikhchandani \& Sharma, 2000, p. 286). One problem with the informational cascade is, as mentioned, the fact that private information does not count once the cascade is rolling, which makes it fragile and highly vulnerable to mass behavior initiated by only the slightest external shock (Bikhchandani et al., 1992, p. 994). The fragility of informational cascades (which can basically be seen as a reflection of the fragility of the market in general) indicates that the borderline between crowd wisdom and pathology is exceptionally thin and 
difficult to comprehend. All in all, whether you land on one side or the other depends on 'who is interacting with whom' as well as 'the level and mode of interaction and interdependence' (Felin, 2012, pp. 289-90).

Ultimately, the wise crowd heavily depends on the exclusion of mimicry from the collective sphere, but it is difficult to imagine a situation in the financial market where any form of social influence on participants is annulled and everyone acts as atomistic individuals. The obsession with purely independent judgments and opinions is, as mentioned, the common denominator between the wisdom-ofcrowds proponents and the contrarians (although the two perspectives differ on whether independence is achievable within a crowd). In order to explicate the intricacy of speculation, the previously mentioned contrarian Thomas Temple Hoyne wrote that ' $[t]$ o speculate successfully is the most difficult of all human activities, and the ability to do it is not to be acquired by any mere monkey-like mimicry of the doings of others, but only by the development of high qualities of intellect, including iron self-control' (Hoyne, 2012 [1922], p. 43). Although mimicry was not a recommended speculation strategy, it was nonetheless tempting to follow the lead of more experienced and seemingly more well-informed investors. Thus, the most crucial and daunting task for contrarian investors was to shield themselves from their own propensity to throw individual judgment to the wind and uncritically rely on imitating others. The contrarian approach was, in itself, a response to what was considered a basic human inclination to affect and be affected by others - a predisposition that was more pronounced in an intense environment such as the financial market. The danger of having your mental machinery thrown out of gear is imminent according to contrarian investment philosophy, but also in the potentially wise market crowd. Mimicry, whether due to seemingly irrational forces derailing the individual investor's mental scheme or due to a deliberate rational choice to imitate, thus seems to be an inevitable condition of investing and speculation. From this, I definitely do not draw the conclusion that traders are, by definition, irrational and therefore that markets are too (O'Hara, 2008, pp. 15-6), but rather stress that the early-20th-century popular finance discourse, including the writings on contrarian 
investing, had a sensibility towards the dynamics of the social in which the market and its participants were embedded. That being said, neither do I wish to suggest that 'folk psychology', as Mirowski terms it in his critique of behavioral economics (Mirowski, 2013, pp. 256-60), holds the explanatory key to the regularly occurring inconsistencies between financial economics theory and the empirical reality of financial markets. Nevertheless, from a sociological perspective, it is interesting how the emphasis on the importance of autonomous decision-making is simultaneously accentuating the influence of inter-subjective dynamics on market movements. Although their bleak diagnosis of the market was perhaps questionable, the contrarians' concern with the ramifications of collective behavior in financial markets remains to this day a recurrent concern that is yet to be fully comprehended.

\section{Conclusion}

This paper has explored the role of the crowd in the financial market by examining the historical origin and theoretical underpinnings of the contrarian investment philosophy. The practice-oriented 'how to' handbooks, in which the contrarian approach unfolded during the 1920s and '30s, brought the crowd (and its mindcorrupting attributes) to the attention of investors, and thus presented the market as anything but an ordered space. I have demonstrated that contrarian investment philosophy grew out of a skepticism, widely shared among financial writers, towards the inclusion of the broader public as participants in the financial market; a skepticism that became a vehicle for the contrarians' essential strategy, which was to identify the crowd in the market and then trade against it at just the right moment. The last decade of the 19th century and the first of the 20th was a period of unrest in the American stock market, with one crisis after another. Given this unruliness, crowd psychology provided convincing explanations of the chaos that occasionally overtook the market.

By adopting ideas and notions from crowd psychology, the 'how to' books on contrarian investing confronted amateur investors with their own psychological 
deficiencies while simultaneously offering remedies in the form of techniques to cope with these shortcomings. Consequently, as this paper has shown, the contrarian investment philosophy provided an opportunity for inexperienced investors to think about investing and speculation in a rather simplistic manner, based on some quite straightforward assumptions about the market participants, and some equally simple techniques and rules. I have argued, in the last section of the paper, that the turning of the crowd-psychology rationale (i.e. that crowds are intellectually inferior to the isolated individual) on its head with the newfound interest in the wisdom of crowds has not rendered all insights from contrarian investing (such as the suggestibility of market actors) obsolete or redundant. On the contrary, examining the recent academic preoccupation with 'crowd wisdom', i.e. the prediction capabilities of crowds, has only affirmed the contrarian thesis that the fragility and vulnerability of individuals, when under the influence of a crowd, translates into a general fragility of the market, which manifests itself in prices.

\section{Acknowledgments}

I am grateful to Christian Borch, Per H. Hansen, Christina Lubinski and Stefan Schwarzkopf for their insightful comments on earlier drafts, as well as Dan Wadhwani and Stephen Dunne for helpful advice. Finally, I like to thank the Economy \& Society editors and anonymous reviewers for their constructive feedback.

\section{Funding}

Research for this paper was supported by a 'Crowd Dynamics in Financial Markets' Sapere Aude Grant from the Danish Council for Independent Research.

\section{Notes}


1 In Confusion de Confusiones (1688), Joseph de la Vega drew attention to an obstructive group of traders 'poisoning the Exchange' by speculating against the market. These traders were known as 'contremines' or countermines, 'a name which is explained by the fact that India is considered to be a mine and that this faction strives to exhaust the mine' (Vega, 1996, p. 162).

2 In stock-market parlance, 'The public comprises the men who come into Wall Street occasionally to speculate' (Marcosson, 1907, p. 104).

3 'Bucketshops used all the paraphernalia associated with established exchanges, such as stock quotes and ticker tape, and established themselves in financial districts, not just in New York and Chicago, but in all major cities in central and western United States' (de Goede, 2005, p. 48). One of the main reasons for the increased number of bucketshops popping up in the last couple of decades of the 19th century was the stock ticker, a price-recording device that enabled bucketshops to get price information at the same time as the exchanges. Edward Calahan of the American Telegraph Company invented the stock ticker in 1867, and Thomas Edison produced an improved version in 1869. Similar to a telegraph machine, the ticker prints stock-price quotations onto ticker tape. This enabled the dissemination of price information without requiring an actual physical presence in the exchange, which radically changed the way markets were organized (Cetina \& Preda, 2007; Knight, 2013, pp. 46-7; Preda, 2006, 2008; Stäheli, 2013).

4 Estimates vary of the number of people owning stocks and bonds in the period from the turn of the century to 'Black Tuesday' in 1929 - some conservative, others perhaps too generous. David Hochfelder conservatively estimates that between 1900 and 1922, stock ownership more than tripled in the United States, from 4.4 million individual owners to 14.4 million, or from $5 \%$ to about $12 \%$ of the population (Hochfelder, 2006, p. 336).

5 'It Pays to be Contrary' is one of the headers in the brochure, and also the title of Neill's 1951 pamphlet (see Neill, 1963, pp. 13-46), in which he outlines his thoughts on the contrarian market philosophy in a formalized manner. 
6 Contrafund's webpage states that its strategy entails 'Investing in securities of companies whose value FMR believes is not fully recognized by the public' (https://fundresearch.fidelity.com/mutual-funds/summary/316071109, accessed on November 15 2014). The mutual fund's founder, Edward C. Johnson Jr., subscribed to Neill's Letters of Contrary Opinion, and later passed his interest in contrary investment strategy on to his son and successor, Edward C. Johnson III (Mintz, 1994, pp. 96-7).

7 If, As \& When was, in Neill's own words, a 'monthly house organ' published by Wetsel Market Bureau Inc., a Manhattan-based investment consultancy. Neill wrote for it under two pseudonyms: 'The Market Philosopher' and 'The Market Cynic'.

8 I have only had access to the Neill Letters of Contrary Opinion from the period 1949-1974 (the 1949-1962 issues courtesy of Dolapo Adeniji-Neill).

9 In general, Hoyne has four rules of thumb for average speculators: 1. 'Do not over-trade'; 2. 'Always definitely fix the amount of profit sought in a speculation and the exact amount of loss that will be submitted to in the effort to secure that profit'; 3. 'Think for yourself; 4. 'Do what you have decided to do' (Hoyne, 2012 [1922], p. 65).

\section{References}

Arnoldi, J., \& Borch, C. (2007). Market Crowds between Imitation and Control.

Theory, Culture \& Society, 24(7-8), 164-180.

http://doi.org/10.1177/0263276407084702

Baruch, B. (1932). Preface. In Extraordinary Popular Delusions and the Madness of Crowds. Amherst, N.Y.: Prometheus Books. 
Bikhchandani, S., Hirshleifer, D., \& Welch, I. (1992). A Theory of Fads, Fashion, Custom, and Cultural Change as Informational Cascades. Journal of Political Economy, 100(5), 992-1026.

Bikhchandani, S., \& Sharma, S. (2000). Herd Behavior in Financial Markets. IMF Staff Papers, 47(3), 279-310.

Black, F. (1986). Noise. The Journal of Finance, 41(3), 529-543. http://doi.org/10.1111/j.1540-6261.1986.tb04513.x

Bollen, J., Mao, H., \& Zeng, X. (2011). Twitter Mood Predicts the Stock Market. Journal of Computational Science, 2(1), 1-8. http://doi.org/10.1016/j.jocs.2010.12.007

Bond, F. D. (1930). Stock Movements and Speculation (Second). New York: D. Appleton and Company.

Borch, C. (2007). Crowds and Economic Life: Bringing an Old Figure Back In. Economy and Society, 36(4), 549-573.

Borch, C. (2012). The Politics of Crowds: An Alternative History of Sociology. Cambridge: Cambridge University Press.

Cetina, K. K., \& Preda, A. (2007). The Temporalization of Financial Markets: From Network to Flow. Theory, Culture \& Society, 24(7-8), 116-138. http://doi.org/10.1177/0263276407084700

Chen, H., De, P., Hu, Y. (Jeffrey), \& Hwang, B.-H. (2014). Wisdom of Crowds: The Value of Stock Opinions Transmitted Through Social Media. Review of Financial Studies, 27(5), 1367-1403. http://doi.org/10.1093/rfs/hhu001 
Cherry, S. (2008). The Ontology of a Self-help Book: A paradox of its own existence. Social Semiotics, 18(3), 337-348. http://doi.org/10.1080/10350330802217113

Conant, C. A. (1901, August). The Uses of Speculation. The Forum, XXXI(6), 698712.

Conant, C. A. (1903, April). The Function of the Stock and Produce Exchanges. The Atlantic Monthly, XCI(DXLVI), 433-442.

Conant, C. A. (1904). Wall Street and the Country: A Study of Recent Financial Tendencies. New York, NY: G. P. Putnam's and Sons: The Knickerbocker Press.

Conant, C. A. (1905, March). How the Stock-Market Reflects Values. The North American Review, 347-359.

Cowing, C. B. (1958). The Discussion of Speculative Competence in America, 19061934. American Quarterly, 10(1), 17-33. http://doi.org/10.2307/2710172

Cowing, C. B. (1965). Populists, Plungers, and Progressives: A Social History of Stock and Commodity Speculation 1890-1936. Princeton, New Jersey: Princeton University Press.

De Goede, M. (2005). Virtue, Fortune and Faith: A Genealogy of Finance. Minneapolis: University of Minnesota Press.

Emery, H. C. (2012). Speculation on the Stock and Produce Exchanges of the United States. Memphis, USA: General Books LLC.

Felin, T. (2012). Cosmologies of Capability, Markets and Wisdom of Crowds: Introduction and Comparative Agenda. Managerial and Decision Economics, 33(5-6), 283-294. http://doi.org/10.1002/mde.2567 
Fraser, S. (2008). Wall Street: America's Dream Palace. New Haven: Yale University Press.

Galbraith, J. K. (1975). The Great Crash 1929: The Classic Account of Financial Disaster (Second). London, England: Penguin Books.

Galton, F. (1907). Vox Populi. Nature, 75(1949), 450-451.

Gottschlich, J., \& Hinz, O. (2014). A Decision Support System for Stock Investment Recommendations Using Collective Wisdom. Decision Support Systems, 59, 52 62. http://doi.org/10.1016/j.dss.2013.10.005

Guyon, D. (1917). One-Way Pockets: The Book of Books on W all Street Speculation. Mankato, MN: Capstone Publishing Company.

Hamilton, W. P. (1922). The Stock Market Barometer. Cosimo Classics.

Harper, H. H. (1926). The Psychology of Speculation: The human element in stock market transactions. N.N.: Henry Howard Harper.

Hill, S., \& Ready-Campbell, N. (2011). Expert Stock Picker: The Wisdom of (Experts in) Crowds. International Journal of Electronic Commerce, 15(3), 73-102. http://doi.org/10.2753/JEC1086-4415150304

Hochfelder, D. (2006). "Where the Common People Could Speculate": The Ticker, Bucket Shops, and the Origins of Popular Participation in Financial Markets, 1880-1920. The Journal of American History, 93(2), 335-358. http://doi.org/10.2307/4486233

Hoyle, W. E. F. (1898). The Game in Wall Street, and How to Play it Successfully. New York: J. S. Ogilvie Publishing Company. 
Hoyne, T. T. (2012). Speculation: Its sound principles and rules for its practice. Memphis, USA: General Books LLC.

Jones, E. D. (1900). Economic Crises. Forgotten Books.

Kelley, E. K., \& Tetlock, P. C. (2013). How Wise Are Crowds? Insights from Retail Orders and Stock Returns. The Journal of Finance, 68(3), 1229-1265. http://doi.org/10.1111/jofi.12028

Kelly, F. C. (1930). Why You Win or Lose: The Psychology of Speculation. Boston: Houghton Mifflin Company.

Keyes, F. C. (1904). Wall Street Speculation: Its tricks and tragedies. Oneonta, NY: Columbia Publishing Company.

Keynes, J. M. (1936). The General Theory of Employment, Interest and Money. London: Macmillan and Co. Ltd.

Kindleberger, C. P., \& Aliber, R. Z. (2011). Manias, Panics and Crashes: A History of Financial Crises (sixth edition). Basingstoke: Palgrave Macmillan.

Knight, P. (2012). Reading the Market: Abstraction, Personification and the Financial Column of Town Topics Magazine. Journal of American Studies, 46(04), 10551075. http://doi.org/10.1017/S0021875811001915

Knight, P. (2013). Reading the Ticker Tape in the Late Nineteenth-Century American Market. Journal of Cultural Economy, 6(1), 45-62. http://doi.org/10.1080/17530350.2012.745439

Leach, E. E. (1986). Mastering the Crowd: Collective behavior and mass society in American social thought, 1917-1939. American Studies, 27(1), 99-114. 
Le Bon, G. (2001). The Crowd: A Study of the Popular Mind. New York: Dover Publications, Inc.

Lorenz, J., Rauhut, H., Schweitzer, F., \& Helbing, D. (2011). How Social Influence can Undermine the Wisdom of Crowd Effect. PNAS, 108(22), 9020-9025.

Mackay, C. (2001). Extraordinary Popular Delusions and the Madness of Crowds. Amherst, NY: Prometheus Books.

Malkiel, B. G. (2012). A Random Walk Down W all Street: The Time-Tested Strategy for Successful Investing. New York: W. W. Norton \& Company, Inc.

Marcosson, I. F. (1907). How to Invest Your Savings. Philadelphia: Henry Altemus Company.

McNeel, R. W. (1921). Beating the Stock Market. N.N.: R. W. McNeel.

Mintz, S. L. (1994). Five Eminent Contrarians: Careers, Perspectives and Investment Tactics. Burlington, VT: Fraser Pub Co.

Mirowski, P. (2013). Never Let a Serious Crisis Go to Waste: How Neoliberalism Survived the Financial Meltdown. London: Verso.

Moore, W. C. (2005). Wall Street: Its mysteries revealed - its secrets exposed. New York: Cosimo, Inc.

Neill, H. B. (1923). Neill-Tyson Service: Including an explanation of the Neill Safety Plan for Market Trading. New York: Neill-Tyson Inc., Investment and Trading Counsel.

Neill, H. B. (1930). If, As and When: Passing Thoughts and Reflections on Human Nature in Finance. Wetsel Market Bureau, Inc.

Neill, H. B. (1951, July 11). Neill Letters of Contrary Opinion. 
Neill, H. B. (1963a). The Art of Contrary Thinking: It pays to be contrary (sixth and enlarged edition). Caldwell, Idaho: Caxton Printers.

Neill, H. B. (1963b, January 9). Neill Letters of Contrary Opinion (No. 1).

Neill, H. B. (2007). Tape Reading and Market Tactics: The Three Steps to Successful Stock Trading. Columbia, MD: Marketplace Books.

Nofer, M., \& Hinz, O. (2014). Are Crowds on the Internet Wiser than Experts? The case of a stock prediction community. Journal of Business Economics, 84(3), 303-338. http://doi.org/10.1007/s11573-014-0720-x

O'Hara, M. (2008). Bubbles: Some perspectives (and loose talk) from history. Review of Financial Studies, 21(1), 11-17. http://doi.org/10.1093/rfs/hhn001

Ott, J. C. (2011). When Wall Street Met Main Street: The Quest for an Investors' Democracy. Cambridge, MA: Harvard University Press.

Pak, S. J. (2013). Gentlemen Bankers: The World of J.P. Morgan. Cambridge, MA: Harvard University Press.

Perkins, E. J. (2012). Julia C. Ott. When Wall Street Met Main Street: The Quest for an Investors’ Democracy. Cambridge, Mass.: Harvard University Press. 2011. The American Historical Review, 117(3), 864-864. http://doi.org/10.1086/ahr.117.3.864

Poitras, G. (2011). Valuation of Equity Securities: History, theory and application. Hackensack, NJ: World Scientific.

Preda, A. (2004). Informative Prices, Rational Investors: The Emergence of the Random Walk Hypothesis and the Nineteenth-Century "Science of Financial Investments". History of Political Economy, 36(2), 351-386. 
Preda, A. (2006). Socio-Technical Agency in Financial Markets: The Case of the Stock Ticker. Social Studies of Science, 36(5), 753-782.

Preda, A. (2008). Technology, Agency, and Financial Price Data. In Living in a Material World (pp. 217-252). Cambridge, MA: MIT Press.

Ray, R. (2006). Prediction Markets and the Financial "Wisdom of Crowds." Journal of Behavioral Finance, 7(1), 2-4. http://doi.org/10.1207/s15427579jpfm0701_1

Schultz, H. D., \& Coslow, S. (1966). A Treasury of W all Street Wisdom. New Jersey: Investors' Press, INC.

Selden, G. C. (1912). Psychology of the Stock Market. New York: Magazine of Wall Street.

Sidis, B. (1919). The Psychology of Suggestion. New York: D. Appleton \& Company. Smith, C. W. (1999). Succes and Survival on Wall Street: Understanding the Mind of the Market. Lanham, Maryland: Rowman \& Littlefield Publishers, Inc.

Smitley, R. L. (1933). Popular Financial Delusions. Philadelphia: Roland Swain Company.

Stäheli, U. (2006). Market Crowds. In J. T. T., Matthew Schnapp (ed.), Crowds. Stanford, California: Stanford University Press.

Stäheli, U. (2013). Spectacular Speculation: Thrills, the Economy, and Popular Discourse. Stanford: Stanford University Press.

Starch, D. (1934). Faith, Fear and Fortune: Why we have booms and depressions - Must we endure them again?. New York: Richard R. Smith.

Surowiecki, J. (2005). The Wisdom of Crowds: Why the Many are Smarter than the few. London, UK: Abacus. 
Tarde, G. (1903). The Laws of Imitation. New York: Henry Holt and Company.

Thomas, P. (1900, October). The Bucket Shop in Speculation. Munsey's Magazine, XXIV(1), 68-70.

Untermyer, S. (1915). Speculation on the Stock Exchanges and Public Regulation of the Exchanges. The American Economic Review, 5(1), 24-68.

Vega, J. de la. (1996). Confusion de Confusiones. In Extraordinary Popular Delusions and the Madness of Crowds and Confusion de Confusiones: Tulipmania, the South Sea Bubble and the Madness of Crowds. New York: John Wiley and Sons, Inc.

Weber, M. (2000). Stock and Commodity Exchanges [Die Börse (1894)]. Theory and Society, 29(3), 305-338. http://doi.org/10.1023/A:1007042728962

Williams, F. J. (1930). If You Must Speculate, Learn the Rules. Fraser Publishing Company.

Winkelman, B. F. (1932). Ten Years of W all Street. Pennsylvania: John C. Winston Co. Withers, H. (1917). Stocks and Shares (second edition). London: John Murray, Albermarle Street, W.

Wyckoff, R. D. (1910). Studies in Tape Reading. New York: Traders Press.

Zhang, X., Fuehres, H., \& Gloor, P. A. (2011). Predicting Stock Market Indicators Through Twitter: "I hope it is not as bad as I fear". In Procedia: Social and Behavioral Sciences, 26, 55-62. http://doi.org/10.1016/j.sbspro.2011.10.562 Zimmerman, D. A. (2006). Panic! Market, Crisis \& Crowds in American Fiction. The University of North Carolina Press. 
Kristian Bondo Hansen is a $\mathrm{PhD}$ fellow at the Department of Management, Politics and Philosophy, Copenhagen Business School, Denmark, and part of a 'Crowd Dynamics in Financial Markets' research project. His research focuses on popular representations of financial markets in the late-nineteenth to mid-twentieth centuries, with a specific emphasis on contrarian investment theory. Forthcoming publications include 'Markets, bodies, and rhythms: A rhythmanalysis of financial markets from open-outcry trading to high-frequency trading' (co-authored w. Christian Borch and Ann-Christina Lange) in Environment and Planning D: Society and Space and a review essay on 'The politics of algorithmic finance' in Contexto Internacional. 